You Can’t Win If You Don’t Fight: The Role of Regime Type in Counterinsurgency

Outbreaks and Outcomes

Anna Getmansky

Forthcoming in the Journal of Conflict Resolution

Introduction

What effect, if any, does democracy have on government's chances to prevail in counterinsurgency wars? ${ }^{1}$ Despite numerous studies there is no conclusive answer. One approach suggests that democracies are less likely to win such wars due to constraints that democratic institutions impose on decision-makers and that hinder their performance (Mack 1975a,b; Krepinevich 1988; Merom 2001; Caverley 2008). An alternative view argues that the key to prevailing in counterinsurgencies is "winning the hearts and minds" of the population by providing public goods (Keefer 2007; Berman, Shapiro, and Felter 2009). ${ }^{2}$ This approach implies that since democracies put a greater emphasis on public goods provision than non-democracies, we can expect them to fare better in counterinsurgencies. Empirical evaluations comparing different regimes' performance in counterinsurgency, however, have not found evidence that regime type affects counterinsurgency outcomes (Engelhardt 1992; Lyall 2010). This result is consistent with the findings of some recent studies on the effects of regime type on military strategies (Downes 2008).

One reason why this question remains unresolved is the challenge of subjecting it to an empirical test. In this study I argue that we might not observe the effect of regime 
type on counterinsurgency outcomes because of its effect on selection into insurgency. Thus, we need to consider which governments face such conflicts in the first place.

In this paper, I draw a connection between selection into insurgency and outcomes of such conflicts. I present several types of evidence to test my argument. ${ }^{1}$ First, using a dataset that includes also lower-intensity conflicts in addition to civil wars and a new coding of outcomes, I find that countries with higher Polity 2 scores have a lower likelihood of experiencing insurgency onsets. However, for those countries that do experience insurgencies, a higher Polity2 score does not affect their likelihood of winning. This finding suggests that if democracies are less likely on average to experience insurgencies compared to non-democracies, then those democracies that end up fighting such conflicts should not differ from non-democracies in their counterinsurgency performance. This is because regime attributes that affect insurgency outcomes influence the government's and the insurgents' initial decision to become involved in such conflict.

Second, I go beyond the aggregate Polity 2 measure and investigate two institutional features that distinguish democracies from non-democracies, and that based on previous studies, can potentially affect insurgency outcomes: institutions associated with public goods provision and institutions that constrain the executives. As I discuss in detail later, these institutions have a negative effect on insurgency outbreaks, but opposing implications on government's likelihood of prevailing in such conflicts. Whereas public goods make governments more likely to win by "buying hearts and

\footnotetext{
${ }^{1}$ Replication materials are available on the publisher's website at http://jcr.sagepub.com/
} 
minds" of the populations, executive constraints make them less likely to prevail by exposing the leaders to violence and casualty aversion of other political players. I test these propositions by evaluating the difference in insurgency onsets and outcomes between (1) political systems that are associated with provision of public goods and those that are not, and (2) between political systems that impose strong constraints on executives and those in which the leaders are less constrained. I use the size of the winning coalition (Bueno de Mesquita et al. 2003) to operationalize political systems that are associated with public goods provision. To measure executive constraints, I use the XCONST variable, which is a component of the Polity2 index. These variables are discussed below.

My empirical results indicate that political systems that are associated with public goods provision are less likely to experience insurgencies in general, as well as specific types of insurgencies (those fought over the control of the central government and separatist insurgencies). In fact, democracies, defined in terms of public goods provision, are less than half as likely to experience insurgency onsets as governments that provide fewer public goods. As a result, we do not get to observe some countries' performance in counterinsurgency simply because they never experience such conflicts in the first place. However, insofar as public goods provision allows the counterinsurgents to "buy the hearts and minds" of the populations, precisely these countries are expected to perform better if they ever experience an insurgency. Thus, this selection mechanism provides an indication that democracies, on average, might in fact be better counterinsurgents. Additionally, I do not find evidence that institutional constraints on the executives affect onsets or outcomes of insurgencies. If democracies were indeed weaker 
counterinsurgents, I would expect that executives subject to stronger constraints would have been less likely to get involved in such conflicts; however, the empirical results do not support this argument.

Before testing the hypotheses, I preprocess the data using matching to account for observable factors that can affect public goods provision, executive constraints, and insurgency onsets and outcomes (a similar method is used in Lyall 2010, although he tests different hypotheses).

This study proceeds as follows. The next section reviews the literature, both theoretical and empirical, on regime type and insurgency outcomes. The third section discusses why taking selection into account is important, and presents the two theoretical mechanisms that connect regime type to insurgency onsets and outcomes. The forth section presents the data, followed by the fifth section that presents the research design. Empirical findings are discussed in the sixth section, and the seventh section concludes. Appendix A contains additional details about the dataset, and Appendix B describes the details matching approach. 
2. Related Literature on Regime Type and Insurgency Outcomes

Previous studies of counterinsurgency provide three different views of the relationship between the counterinsurgent's regime type and outcomes of such conflicts.

One approach suggests that the key to winning in counterinsurgencies is the government's ability to use coercive power to inflict pain and raise the fighting costs to insurgents and their supporters (Leitis and Wolf 1970; Arreguin-Toft 2005). The implication of this view is that democracies might be less likely to win counterinsurgencies because of the institutional constraints on the government that limit their ability to apply military force (Mack 1975a,b; Merom 2001; Arreguin-Toft 2005; Karol and Miguel 2007; Iyengar and Monten 2008; Caverley 2009). Autocratic leaders, conversely, are perceived to be free to use as much violence as necessary, and therefore are in a better position to win counterinsurgency wars (Zhukov 2007).

Contrary to this view, empirical studies find only weak evidence, if any, that democracies are more constraint in their use of force (Downes 2008; Valentino, Huth, and Balch-Lindsay 2004; Morrow 2007). Moreover, some studies show that indiscriminate violence can be counterproductive (Kalyvas 2006, 151-153), that evidence regarding casualty aversion is more nuanced (Feaver and Gelpi 2004), and that nondemocracies can also be vulnerable to insurgency costs (Wood 2000). Additionally, the argument that democracies fare worse in counterinsurgency is contradicted by their record in interstate wars which democracies overwhelmingly win (Reiter and Stam 2002; Bueno de Mesquita et al. 2003, 2004). 
An alternative view connects victory with public goods provision (Galula 1964; Krepinevich 1988), and implies that democracies might be better positioned to win such wars because they provide more public goods than non-democracies (Bueno de Mesquita et al. 2003, 91-99, 101, 179-195; Bueno de Mesquita and Smith 2009). Keefer (2007) argues that the ability of leaders to make credible commitments to larger segments of their citizenry is a decisive factor in preventing insurgencies in the first place, and in government's ability to win them should they erupt. Similarly, Berman, Shapiro, and Felter (2009) demonstrate that the most effective way to prevail in a counterinsurgency is by providing public goods to "win the hearts and minds" of the population.

Finally, a third approach maintains that there is no evidence that regime type is related to counterinsurgency outcomes (Engelhardt 1992; Lyall 2010), which are determined by alternative factors, such as the strategies employed by the belligerents (Arreguin-Toft 2005), the level of military mechanization (Lyall and Wilson 2009), and external assistance to insurgents (Record 2007). 
3. Regime Type and Insurgency Onsets and Outcomes

\subsection{Potential Selection Effects}

One reason why there is no conclusive answer to whether regime type matters to counterinsurgency outcomes is because of selection effects that shape who gets involved in such conflicts in the first place. Rational players select themselves into conflicts based on their anticipation of the opponent's response and based on their prior belief about the outcome of such conflicts. The literature on interstate wars emphasizes the role of selection effects in explaining deterrence failure (Achen and Snidel 1989; Fearon 2002), alliance reliability (Smith 1995), conflict escalation (Reed 2000; Lemke and Reed 2001), and conflict expansion beyond the initial participants (Gartner and Siverson 1996). In addition, selection effects have been applied to explain why democracies tend not to fight with each other (Bueno de Mesquita et al. 2003), and why they tend to win most of the wars they fight (Bennet and Stam 1996; Bueno de Mesquita et al. 2003). In the civil war literature, Lacina (2006) applies the selection logic to test the effect of democracy on civil war severity.

In this paper, I build on this logic and draw a connection between selection into insurgency and outcomes of such conflicts. I propose that if regime type affects counterinsurgency performance, then this effect should be evident at the stage of selection into a conflict. That is, if democracies are more effective counterinsurgents, then they should be challenged less by insurgents. Conversely, if democratic institutions inhibit government's counterinsurgency performance, then these governments might be challenged more often, but they should also have incentives to avoid fighting by offering 
concessions and co-opting the potential insurgents (Lacina 2006). Whatever the mechanism is, the effect of democratic institutions, if it exists, should influence the players' decision to become involved in insurgency. Once these decisions are made, governments' regime type should not their chances of winning, keeping other factors that affect insurgency outcomes constant.

Most of the studies on onsets of civil wars uncovered only mixed statistical results regarding the relationship between democracy and such conflicts (Collier and Hoeffler 2000; Hegre et al. 2001; Fearon and Laitin 2003; Vreeland 2008). Some find that anocracies (political systems with midlevels of democracy) are positively associated with a higher risk of civil war outbreak (Sambanis 2001, Hegre et al. 2001, Fearon and Laitin 2003), but Vreeland (2008) convincingly shows that this result is not causal, but is due to the effect of violence on some components of the Polity index. The finding that democracy does not affect civil war onset is especially puzzling given the expectation that democracies should experience less domestic political violence because their institutions provide a possibility for a peaceful collective action, whereas the lack of political freedoms can motivate grievances and lead to violence in non-democracies (Gurr 1970, 332).

Among studies that report an effect of political regime on civil war onsets, Elbadawi and Sambanis (2002) find that democracy is negatively associated with the prevalence (onset and duration) of civil wars. In addition, Reynal-Querol (2002) points to political inclusiveness (one of the properties that distinguish democracies from other regime types) as the main determinant of civil wars, and finds that revolutionary civil wars are most likely in presidential systems with lower levels of democracy. 
Thus, if there is a relationship between the overall level of democracy, onset, and outcomes of insurgencies, then based on the selection logic and previous studies I expect to find the following:

Hypothesis 1A: Democratic countries are less likely to experience insurgencies.

Hypothesis 1B: Among countries that experience insurgencies, the outcomes of insurgencies will be uncorrelated with the level of democracy.

\subsection{How Does Regime Type Determine Onsets and Outcomes of Insurgencies?}

Scholars of intrastate conflict and terrorism have also engaged in debates over which attributes of regime type affect the probability and outcomes of such conflicts. Moreover, some components of political regime can have countervailing effects that cannot be detected in empirical tests that use an aggregate regime measure. Two theoretical arguments in the literature predict opposite effect of some regime attributes on onsets and outcomes of insurgencies. The first argument suggests that democratic countries are less likely to experience insurgencies because they are more responsive to their populations, and are better able to make credible promises to large segments of their citizenary by providing public goods (Keefer 2007). This also makes them better counterinsurgents because they are better able to construct a counterinsurgency capacity. The second argument posits that institutional constraints on the government in democracies may encourage insurgencies by making democratic governments less effective counterinsurgents (Li 2005). I explore these arguments below and derive hypotheses for empirical tests.

(1) Public Goods, Onsets and Outcomes of Insurgencies. 
Existing literature identifies popular support as one of the most important determinants of insurgency onset and outcomes (Galula 1964; Berman, Shapiro, and Felter 2009). The most prevalent explanation is that insurgents and counterinsurgents use popular support to gain crucial information that allows them to be more effective in combat by directly targeting the opponent and the opponent's supporters (Kalyvas 2006).

Previous studies suggest that public support directly depends on the amount of public goods provided by the government. Public goods provision can affect insurgency onsets and outcomes through two mechanisms. First, as suggested by Keefer (2007), underprovision of public goods makes the citizens indifferent, at best, between the current regime and any potential challenger. This, in turn, makes insurgency onsets more likely because challengers have a better chance to get the support they need to organize a rebellion. A related argument maintains that provision of public goods makes insurgencies less likely because it satisfies some of the potential insurgents' demands, and dissuades them from pursuing their demands violently. Second, underprovision of public goods makes it harder and costlier for the government in power to build an antiinsurgency capacity. Governments that do not provide enough public goods often lack the infrastructure required to fight insurgencies (such as roads and well trained security forces). In addition, Berman, Shapiro, and Felter (2009) show that in the case of the US counterinsurgency in Iraq, public goods and public support are linked to better intelligence gathering that in turn improves the governments chances to win.

These arguments suggest that governments that provide more public goods are less likely to be involved in insurgency because they enjoy more public support than governments that provide fewer public goods. In addition, this support also makes these 
governments more likely to prevail conditional on being involved in such conflicts than governments that provide fewer public goods:

Hypothesis 2A: Governments that provide more public goods are less likely to experience insurgencies.

Hypothesis 2B: Conditional on experiencing insurgencies, provision of public goods is positively associated with government victory.

(2) Institutional Constraints, Onsets and Outcomes of Insurgencies.

Existing literature also suggests that institutional constraints on the executive might affect onsets of insurgencies and their outcomes. Different regimes differ in the extent to which the decision-making power of government is constrained by other institutions, such as legislatures, courts, and elections. Democratic governments face a wider range of constraints over their ability to exercise power compared to nondemocratic governments. These institutional differences imply that multiple veto players in democracies make it more difficult for democratic governments to enact costly counterinsurgency policies (Li 2005). Additionally, democratic governments are constrained by and are held accountable to a broader range of societal interests. In the context of interstate conflict, Morgan and Campbell (1991) argue that democratic institutions that diffuse decision-making authority make it easier for those with dovish preferences to veto a resort to force. Merom (2001) makes a similar claim with respect to insurgencies, and suggested that democracies are more averse to violence and casualties, and thus are less effective counterinsurgents than non-democratic governments. These arguments suggest that democratic leaders tend to have a lower expected utility from 
fighting, and a greater incentive to avoid such conflicts compared to non-democracies (Schultz 1999).

According to this logic, then, institutional constraints on the executive should be associated with lower probability of insurgency because more constrained governments, anticipating their weakness, will try to avoid such conflicts by cutting deals with potential insurgents. In addition, among governments experiencing insurgencies, higher institutional constraints should be associated with lower chances of winning:

Hypothesis 3A: Governments with more institutional constraints experience less insurgency.

Hypothesis 3B: Conditional on experiencing insurgency, governments with more institutional constraints are less likely to win. 
4. Data

This is a time-series-cross-sectional dataset that includes all countries with population above 1 million from 1950 to $2007 .{ }^{3}$ For each country-year there are binary variables that indicate whether it experienced an insurgency onset, an ongoing insurgency, or an insurgency termination based on the Armed Conflicts Dataset. ${ }^{4}$ Insurgency is defined as a violent struggle between a government and a non-state group that is fighting either to overthrow the incumbent and take control of the government, or to gain regional independence or a greater autonomy. ${ }^{5}$ This definition excludes intercommunal violence and cases of governments intervening in foreign insurgencies, such as the US in Vietnam (albeit I include these wars from the perspective of the local government and control for foreign assistance). Foreign interventions are not included because the selection mechanisms into such wars are different from selection into domestic insurgencies. For termination years there is an indicator of insurgency outcome coded using a flexible coding scheme that allows different definitions of victory (described below). Including country-years that do not experience insurgencies makes this dataset applicable to estimating the effect of regime type on selection into insurgency. In addition, the dataset covers not only civil wars, but also insurgencies with less than 1000 casualties, provided they cross the 25 casualties threshold in a given year. This broader definition of insurgency not only incorporates more cases, but also avoids a potential bias that can occur if civil wars are not randomly distributed between democracies and non-democracies. The initial dataset contained some missing values that I imputed using the Amelia II software (Honaker, King, and Blackwell 2010). The 
results reported here are based on the imputed dataset. They do not change substantially if we run the analysis without the imputation (ignoring the missing values).

\subsection{Dependent Variables: Insurgency Onsets and Outcomes}

The dependent variable for testing hypotheses $1 \mathrm{~A}, 2 \mathrm{~A}$, and $3 \mathrm{~A}$ is whether a given country experiences an insurgency onset in a given year based on the Armed Conflicts Dataset. The dependent variable for testing hypotheses $1 \mathrm{~B}, 2 \mathrm{~B}$ and $3 \mathrm{~B}$ is whether a government experienced a victory in a given year, conditional on having an insurgency.

Since the Armed Conflicts Dataset (Gleditsch et al. 2002) does not code outcomes of conflicts, I coded them based on the Europa World description and supplemented, if needed, by additional sources. Each conflict termination is first coded as an ordinal variable along five points, and then converted into a dichotomous variable coded 1 if government wins and 0 otherwise. Table 6 lists the categories of the ordinal variable, the explanations for the coding, and the shares of each outcome in this dataset.

[Table 1 about here.]

Government victory is coded 1 if the outcome falls in category 4 , and it is coded 0 if it falls in other categories. For the purpose of robustness checks (not reported here) I also considered a broader definition of victory (categories 3 and 4). This does not change the substantive results.

4.2 Main Independent Variables: Democracy, Public Goods Provision, and Executive Constraints. 
To test hypotheses 1A and 1B, I measure democracy using the Polity2 score (lagged one year). Democracy is coded 1 if a country's Polity2 score is 7 or above, and 0 otherwise. $^{6}$

I operationalize public goods provision in hypotheses $2 \mathrm{~A}$ and $2 \mathrm{~B}$ using the size of the winning coalition based on the selectorate theory (Bueno de Mesquita et al. 2003). This theory distinguishes among political systems based on two institutional features that determine how they select and retain leaders: the size of selectorate (S) and the size of the winning coalition $(\mathrm{W})$. $\mathrm{S}$ is the set of people in the polity who can take part in choosing a leader. $\mathrm{W}$ is the share of selectors whose support the leader must retain to remain in office. Democracies have large S and W, although the exact size of each varies with the precise electoral rules in each political system. Non-democracies have small winning coalitions, but vary in the size of the selectorate (monarchies, for example, have small S, whereas one-party autocracies have a large selectorate). To maintain the support of the winning coalition and to remain in power, leaders provide public and private goods to the members of their W. All leaders provide both types of goods, but their mix varies in the size of $\mathrm{W}$. What makes the $\mathrm{W}$ a good indicator of public goods provision is that as the size of $\mathrm{W}$ increases, leaders shift away from private benefits and toward public goods. This is because a larger $\mathrm{W}$ means more supporters to please, spreading out private benefits, and making public goods a more efficient way for the leader to retain the support of his support coalition (Bueno de Mesquita et al. 2003, 2008).

The size of $\mathrm{W}$, therefore, captures the extent to which a government emphasizes public goods in its policies. The variable, constructed by Bueno de Mesquita et al. (2003), takes the values of $0,0.25,050,0.75$, and $1 .^{7}$ I use a binary measure coded 1 if $\mathrm{W}$ is 
greater or equal to 0.75 , and coded 0 otherwise. For the purpose of robustness checks, I also test the hypothesis on an alternative definition of $\mathrm{W}=1$.

The third independent variable of interest is the extent to which an executive's ability to launch a counterinsurgency campaign is constrained by other political players and institutions. A variable that captures the constraints mechanism is XCONST, which is part of the Polity 2 index. It measures the institutional constraints to the leaders' unilateral decision-making that emanate from other political institutions such as legislatures and courts. ${ }^{8}$ Such constraints make leaders take into account other players' resolve to incur casualties and use violence, and this, according to some previous studies discussed above, disadvantages democracies compared to non-democracies whose leaders are subject to fewer constraints. XCONST ranges from -3 to 4 , with -3 describing an unconstrained executive and 4 capturing the highest level of executive constraints. For the purpose of testing hypotheses $3 \mathrm{~A}$ and $3 \mathrm{~B}$, I converted XCONST into a dichotomous variable that is coded 1 if XCONST is greater or equal to 3, and 0 otherwise.

XCONST is particularly suitable in our context also because it is not part of the W measure, and thus allows separating the two explanations. Additionally, XCONST is not affected by the presence of insurgencies and can therefore be used as an independent variable to explain them (Vreeland 2008). Finally, previous studies use XCONST to operationalize executive constraints in the context of domestic political violence ( $\mathrm{Li}$ 2005). 


\section{Research Design}

Before turning to the empirical tests, I briefly discuss two potential sources of bias that need to be addressed. They can be clarified using a medical analogy. Suppose we wanted to test whether higher doses of vitamin $\mathrm{C}$ reduce the likelihood of dying from flu, and we randomly assigned high doses of this vitamin to flu patients that were hospitalized with the disease. Assume also that after some time we did not find any difference in the death rates between those who received vitamin $\mathrm{C}$ and those treated with a placebo. Despite these results, we cannot conclude that vitamin $\mathrm{C}$ is useless against the flu because it can prevent people from catching the decease in the first place, or if they become infected, it can help reduce their symptoms so that they do not have to be hospitalized.

In this paper democracy is equivalent to treatment with vitamin $\mathrm{C}$, and counterinsurgency losses correspond to flu casualties. The medical example highlights two potential sources of bias. First, we need to consider not only cases of insurgencies that escalated to full-scale civil wars (the equivalent of hospitalized patients), but also less severe conflicts that do not cross the threshold of 1000 casualties to be considered as civil wars. Most of the studies that concluded that democracy does not affect insurgency onsets focused on civil wars (Collier and Hoeffler 1998; Hegre et al. 2001; Fearon and Laitin 2003; Vreeland 2008), thereby ignoring conflicts of lower intensity. ${ }^{9}$ Studies that included lower-level conflicts yield mixed results. ${ }^{10}$ Thus, even if democracy does not affect outbreaks of civil wars, it might still lower the risk of lower-intensity insurgencies. I address these concerns by including insurgencies below the civil war threshold, and examining whether democracy prevents all types of insurgencies from breaking out in the first place. 
Second, in evaluating the effect of democracy on outcomes of insurgencies it is useful to think about regime as a treatment, and about onsets and outcomes of insurgencies as the effects of this treatment. However, unlike the vitamin $\mathrm{C}$ treatment, regime types cannot be randomly assigned. Thus, some of the regime determinants might also influence whether insurgencies break out in the first place as well as their outcomes. If this is the case, then any association (or lack thereof) between democracy and outcomes of insurgencies can occur not due to regime type, but due to other confounding variables. ${ }^{11}$ Ho et al. (2007) explain that simply controlling for the confounding factors by adding them to a regression is not enough if they are not equally distributed between the treatment (democracies) and the control (non-democracies) groups. Existing studies on the effect of democracy on onsets and outcomes of civil wars, with the exception of Lyall (2010), do not address this concern.

I address this possibility using a nearest neighbor matching design that allows to pair countries such that in each pair one country is a democracy and another is not although they are as similar as possible with regard to all other observable aspects that could potentially be relevant both to insurgency onsets, outcomes, and regime type assignment. ${ }^{12}$ Similarity does not imply that all the members of both groups should have identical values of the confounding variables. Rather it means that the distribution of these variables should be as similar as possible (Ho et al. 2007).

In this paper I consider three binary definitions of democracy: Polity 2 score is 7 or above, size of the winning coalition (W) is 0.75 or above, and XCONST is 3 or above. I match democratic and non-democratic country-years using variables that previous studies have identified to have an effect on political institutions and also on onsets of 
insurgencies. Specifically, I match on income, urbanization, oil production, ethnic and religious fractionalization, foreign assistance to the government, years since independence, colonial past, and share of Muslim population. I discuss these variables, the justification for their inclusion, and provide examples of balance statistics in the online appendix.

Some observations are discarded in the process of matching if they are too different from the units in the other group. Discarding observations might seem problematic because we are usually interested to include as many cases as possible in the estimation. However, if the data contains cases to which no similar counterfactuals can be found then including them in the estimation process increases the reliance on functional form assumptions (King and Zeng, 2006).

In this context it is important to reiterate that matching does not solve all the potential problems. For example, there might be some factors that are unobservable, and we cannot match on them. There are alternative techniques, such as the Heckman selection model, but they suffer from other disadvantages. In addition to the difficulty of finding a good instrument, the Heckman model also depends on the functional form of the selection equation (this means we make assumptions about how regime is assigned to countries, and not only about which factors affect this assignment).

After matching, I estimate the following probit model to test hypotheses $1 \mathrm{~A}, 2 \mathrm{~A}$, and 3A on insurgency onsets:

$y_{\text {it }}=\beta_{0}+\beta_{1} \times$ Regime $_{i t}+\beta_{2} \times \log \left(\right.$ GDPpc $\left._{i t}\right)+\beta_{3} \times \log \left(\right.$ population $\left._{\text {it }}\right)$ 


$$
\begin{aligned}
& +\beta_{4} \times \log \left(\% \text { mountainous }_{\mathrm{it}}\right)+\beta_{5} \times\left\{\text { non-continuous territory }_{\mathrm{it}}\right) \\
& +\beta_{6} \times\left\{\text { oil }_{\mathrm{it}}\right)+\beta_{7} \times\left(\text { ethnic fractionalization }_{\mathrm{it}}\right)+\beta_{8} \times(\text { religious } \\
& \text { fractionalization } \left._{\mathrm{it}}\right)+\varepsilon_{\mathrm{it}}
\end{aligned}
$$

where $y_{i t}$ is coded 1 if there is an insurgency onset in country $i$ in year $t$, and 0 otherwise. The models include independent variables from Fearon and Laitin's (2003) dataset and cubic splines on years without onsets to account for temporal dependence (Beck, Katz, and Tucker 1998). ${ }^{13}$. I test this model on all country-years after matching on the probability of Polity $2 \geq 7, \mathrm{~W} \geq 0.75$, and $\mathrm{XCONST} \geq 3$ that I use as measures of regime.

To estimate hypotheses 1B, 2B, and 3B on insurgency outcome, I use the following probit specification:

$$
\begin{aligned}
& y_{\text {it }}=\beta_{0}+\beta_{1} \times \text { Regime }+\beta_{2} \times \log \left(\mathrm{GDPpc}_{\mathrm{it}}\right)+\beta_{3} \times \log \left(\text { population }_{\mathrm{it}}\right. \\
& +\beta_{4} \times \log \left(\% \text { mountainous }_{\mathrm{it}}\right)+\beta_{5} \times\left\{\text { non-continuous territory } \mathrm{it}_{\mathrm{it}}\right) \\
& +\beta_{6} \times\left\{\text { oil }_{\text {it }}\right)+\beta_{7} \times\left(\text { ethnic fractionalization }_{\mathrm{it}}\right)+\beta_{8} \times(\text { religious } \\
& \text { fractionalization } \left._{\mathrm{it}}\right)+\beta_{9} \times\left(\text { gov't foreign support }_{\mathrm{it}}\right)+\beta_{10} \times(\text { insurgents' foreign } \\
& \text { support } \left._{\mathrm{it}}\right)+\varepsilon_{\mathrm{it}}
\end{aligned}
$$

where $\mathrm{y}_{\mathrm{it}}$ is coded 1 if government $i$ won in year $t$, and 0 otherwise, conditional on having an insurgency. As before, I included cubic splines to account for temporal dependence. I test this model on a sample of country-years engaged in a insurgency and matched on the probability of Polity $2 \geq 7, \mathrm{~W} \geq 0.75$, and $\mathrm{XCONST} \geq 3$. 


\section{Findings}

\subsection{Effect of Overall Democracy Level (Hypotheses 1A and 1B)}

Table 2 columns (1) and (2) show the results of a probit model of insurgency onsets (hypothesis 1A) in the pre-matched (full) and matched samples (I match on the probability of Polity $2 \geq 7$ ).

\section{[Table 2 about here.]}

These results indicate that whereas Polity 2 score is not significantly associated with insurgency onsets in the full sample, its coefficient becomes negative and significant once we match on the probability of Polity $2 \geq 7$. The size of the coefficient also becomes bugger in the matched sample. Some country-years are discarded in the process of matching if they do not have a close match. For example, the US is completely dropped from the matched sample because there is no non-democratic country that resembles the US on such factors as per capita income, urbanization, and education. Likewise, the most of the year of Soviet Union, Argentina, Brazil, Venezuela, Paraguay, and China are also dropped because there are no democracies that closely resembled them. These countries did not experience many insurgencies and were autocratic during most of the period covered in this paper. Removal of these country-years increases the share of nondemocratic country-years with insurgency, and therefore contributes to the negative effect of democracy on insurgency onset that is reported in the analysis of the matched sample.

Most control variables have the anticipated effect: GDP per capita has the expected negative and significant sign in both samples, and population size is positive and 
significant. Ethnic fractionalization appears to have a positive and significant association with insurgency onsets, but it disappears in the matched sample. Countries with noncontinuous territory are also more likely to experience insurgencies, and this result is significant in the matched sample. Elevation and oil lose their explanatory power once matching is applied.

I now turn to test hypothesis $1 \mathrm{~B}$ on the effect of Polity 2 score on outcomes of insurgencies that break out. Table 2 columns (3) and (4) present the estimation of the preand the post-matching sample. The results of the full sample show that higher levels of Polity2 are negatively and significantly associated with government victory in the unmatched sample; however, in line with Lyall's (2010) findings, this result is not significant at conventional levels when matching is applied. Income and oil also turn insignificant following matching. Population size, ethnic fractionalization, noncontiguous territory and mountainous terrain appear to be negative determinants of government victory.

6.2 Effect of Public Goods Provision (Hypotheses 2A and 2B)

Table 3 presents the results for hypothesis $2 \mathrm{~A}$ (the effect of public goods provision on insurgency onsets) conducted using a matched sample of country-years paired based on their probability of having a large winning coalition ( $\mathrm{W} \geq 0.75)$. The effect of $\mathrm{W}$ is statistically significant and negative across different specifications, consistent with hypothesis 2A. Columns (1) and (2) report the analysis for all countries in the matched sample. Column (1) shows the results of specification with XCONST, and Column (2) reports the results once XCONST is dropped. Contrary to the negative and 
significant effect of $\mathrm{W}, \mathrm{XCONST}$ is not significant, and its removal from the model does not change the results. Columns (3) and (4) restrict the analysis to separatist insurgencies, and columns (5) and (6) focus on those insurgencies that are fought over the control of the central government. The results here indicate that among countries that are similar with regard to factors such as GDP per capita, urbanization, ethnic and religious fractionalization, time since independence and colonial past, an increase in the size of the winning coalition is associated with a decrease in the probability of insurgency.

[Table 3 about here.]

The average marginal effect of a transition from $\mathrm{W}<0.75$ to $\mathrm{W} \geq 0.75$ (setting the other variables at their means) is a decrease of $1.7 \%$ in insurgency probability. I estimate it using Zelig software (Imai, King, and Lau 2007). A 95\% confidence interval is [-3.3\% $0.5 \%]$. We should not infer from this small percentage that $\mathrm{W}$ is negligible because insurgencies themselves are rare events. A more useful quantity to focus on is a risk ratio: $\frac{\mathrm{P}(\mathrm{Y}=1 \mid \mathrm{W} \geq 0.75)}{\mathrm{P}(\mathrm{Y}=1 \mid \mathrm{W}<0.75)}=0.51(\mathrm{Y}=1$ indicates an insurgency onset $)$. This expression shows that large $\mathrm{W}$ systems are half as likely to experience insurgencies as small $\mathrm{W}$ systems. The confidence interval is $[0.30 .8]$.

To subject these results to further scrutiny, I conducted the analysis using $\mathrm{W}=1$ as a definition of treatment, and it produced similar results.

Several examples illustrate this result. Lebanon prior to 1975 civil war had a relatively large winning coalition $(\mathrm{W}=0.75)$, and relatively low executive constraints (XCONST $=-1$ for most of the years). During this period, Lebanon enjoyed more stability 
and less violence compared to countries with similar executive constraints, but smaller winning coalitions, such as Jordan. An additional example is the comparison between Portugal in 1964 and Romania in 1992. These two countries are a good match with respect to their income per capita, oil, and female-to-male ratio in primary education, but differ in the size of their winning coalition (Romania has a large winning coalition of 0.75 , and Portugal has a smaller winning coalition of 0.5 ). Portugal experienced an insurgency onset, whereas Romania remained peaceful despite being more ethnically diverse and more rural. Another example that illustrates the negative effect of the size of the winning coalition on insurgency onsets is the case of Turkey, where the winning coalition decreased from $\mathrm{W}=0.75$ to $\mathrm{W}=0.5$ following a coup in 1980 , and in 1984 Turkey experienced an onset of a Kurdish separatist insurgency.

I now proceed to test hypothesis $2 \mathrm{~B}$ (the effect of public goods provision on insurgency outcomes). The results are in Table 4.

[Table 4 about here.]

None of the regime aspects are significant for victory in the sample of pooled insurgencies. GDP per capita appears to be the only variable that is positively and significantly associated with victory in both models. Non-continuous territory also appears to make victory less likely, except for the last model. The results do not change when I exclude countries fighting rebels that cannot be part of the government's winning coalition, for example the Palestinian insurgency against Israel and the Malaya insurgency. ${ }^{14}$

6.3 Effect of Executive Constraints (Hypotheses 3A and 3B) 
Table 5 presents the results of hypotheses $3 \mathrm{~A}$ tests of the effect of executive constraints on onsets of insurgencies. I used a sample of country-years matched on the probability of XCONST $\geq 3$. As before, I first pool all insurgencies together, and then separate by type. As with hypothesis $2 \mathrm{~A}$, I first tested the model only with XCONST, and then added W. These tests demonstrate that among countries that are as similar as possible on a number of observable factors that affect political institutions and onsets of insurgencies, higher levels of executive constraints do not affect onsets of insurgencies, whereas larger winning coalition is associated with lower probability of insurgency onsets. These results are consistent with hypothesis $2 \mathrm{~A}$, but not with hypothesis $3 \mathrm{~A}$.

[Table 5 about here.]

Finally, Table 6 presents the results of hypothesis 3B test. Column (1) shows that the sign of XCONST is consistent with the argument that constraints make governments less likely to win, but it is not significant at an acceptable level. The inclusion of the size of the winning coalition in column (2) does not change these results, and $\mathrm{W}$ is also not statistically significant. In this model, as in the test of hypothesis 2B, GDP per capita remains a good predictor of insurgency outcomes. In addition, non-continuous territory also appears to make victory less likely. These results do not change when I exclude countries fighting rebels that cannot be part of the government's winning coalition, for example the Palestinian insurgency against Israel and the Malaya insurgency. ${ }^{15}$ XCONST also does not have a significant effect on government's victory when tested separately on separatist and center-oriented insurgencies (these results are not reported here).

[Table 6 about here.] 


\section{Conclusions}

In this study I argue that we might not be able to directly observe the effect of regime type on insurgency outcomes due to its effect on selection into insurgency. Conflicts occur because both the insurgents and the government believe that settling is not advantageous from their perspective. If both reach this conclusion, then regime becomes irrelevant to insurgency outcomes. This is because any effect that regime type might have on the government's counterinsurgency effectiveness should be part of the initial decision of both sides to become involved in such conflicts. Governments that choose fighting over settling cannot be especially vulnerable to insurgencies because then they should have tried to avoid them by cutting deals with the rebels. Similarly, they also cannot be especially well positioned to win because then they would not have been challenged.

In this paper I provide evidence of one way that democracies might be selected out of insurgencies, namely through the provision of public goods. As a result, those democracies that are not successful in avoiding insurgencies by providing public goods do not differ much from the non-democracies that fight such insurgencies. I do not find evidence, however, that institutional constraints affect selection into insurgencies or victory in such conflicts. I interpret this finding as evidence that democracies are not worse counterinsurgents due to institutional constraints on the executive's powers, such as strong legislatures and courts. Thus, the argument that such democratic institutions inhibit government's performance in counterinsurgency is not supported by the evidence I present here. 
8. Appendix A - Data

This is a time-series-cross-sectional dataset that includes all countries with population above 1 million from 1950 to $2007 .{ }^{16}$ For each country-year there are binary variables that indicate whether it experienced an insurgency onset, an ongoing insurgency, or an insurgency termination based on the Armed Conflicts Dataset. ${ }^{17}$

I define insurgency as a violent struggle between a government and a non-state group that is fighting either to overthrow the incumbent and take control of the government, or to gain regional independence or a greater autonomy. ${ }^{18}$ This definition excludes intercommunal violence and cases of governments intervening in foreign insurgencies, such as the US in Vietnam (albeit I include these wars from the perspective of the local government and control for foreign assistance). Foreign interventions are not included because the selection mechanisms into such wars are different from selection into domestic insurgencies.

For termination years there is an indicator of insurgency outcome coded using a flexible coding scheme that allows different definitions of victory (described below).

Including country-years that do not experience insurgencies makes this dataset applicable to estimating the effect of regime type on selection into insurgency. In addition, the dataset covers not only civil wars, but also insurgencies with less than 1000 casualties, provided they cross the 25 casualties threshold in a given year. This broader definition of insurgency not only incorporates more cases, but also avoids a potential bias that can occur if civil wars are not randomly distributed between democracies and nondemocracies. 
The initial dataset contained some missing values that I imputed using the Amelia II software (Honaker, King, and Blackwell 2010). The results reported here are based on the imputed dataset. They do not change substantially if we run the analysis without the imputation (ignoring the missing values).

Below I present the dependent and the main independent variables. Appendix B that discussed matching contains details about the control variables. 
Appendix B - Matching

\section{Confounding Variables}

Confounding factors are those variables that (1) influence the dependent variable conditional on treatment, (2) are correlated with the treatment, and (3) are prior to the treatment (Gilligan and Sergenti 2007; Morgan and Winship 2007). Below is a list of confounding factors used in this analysis and a brief explanation of why they were included.

1. GDP per capita is considered to be a determinant of democracy (Barro 1999; Przeworski et al. 2000) and has an impact on insurgency (Fearon and Laitin 2003;

Collier and Hoeffler 1998). The empirical part uses one year lagged log of GDP per capita based on the Penn World Table data version 6.3 (the rgdpch variable, which measures real GDP per capita chain series expressed in 2005 constant prices). ${ }^{19}$

2. Urbanization influences democracy (Barro 1999). In addition, Fearon and Laitin (2003) point out that rural areas are more prone to insurgencies because guerrilla fighters have more places to hide, whereas in cities government forces can more easily detect them. I use the WDI measure of the percentage of rural population.

3. Natural resources lower the level of democracy (Barro 1999; Ross 2003; Jensen and Wantchekon 2004) and increase the probability of conflicts (Collier and Hoeffler 1998; Fearon and Laitin 2003). In this paper I match on whether a country is a major exporter of oil (more than one thirds of its exports come from oil). This variable is based on Fearon and Laitin's dataset. 
4. Ethnic and religious fractionalization is negatively associated with democracy (Barro 1999). Even though Fearon and Laitin (2003) show that ethnic fractionalization is not a good determinant of conflicts, some still consider it to be an important factor in where insurgencies occur and how they end (Montalvo and Reynal-Querol forthcoming). I use measures of ethnic and religious fractionalization from Fearon and Laitin's dataset.

5. External support to the government can affect both regime and the outcomes of insurgencies. Foreign aid negatively affects democracy (Bueno de Mesquita et al. 2003; Bueno de Mesquita and Smith 2009). In addition, it can make the government more likely to win by providing it with counterinsurgency resources (Record 2007). This is an ordinal variable coded 0 if the government receives no external support, 1 if the government receives passive (weapons or advisers from other governments), and 2 if troops from other countries are actively fighting on the side of government forces.

6. New state (less than 2 years since the independence) can be more prone both to democratic instability and insurgency (Fearon and Laitin 2003; Wantchekon 2004).

I also match on whether a country is a former British colony and on the share of Muslim population. There is no theory that connects these variables to onsets or outcomes of insurgencies, but because they are strong determinants of democracy I also include them in matching (Barro 1999). 
In addition, I control for the following variables that can affect insurgency onsets and outcomes: external support for insurgents, terrain, population size, and non-continuous territory.

Matching Results - Checking the Balance

I use nearest neighbor matching with replacement to match treatment unit to a control unit that is the closest to it on its distance measure with respect to the confounding factors. Replacement means that each control unit can be assigned to more than one treatment unit. In addition, I discard observations that lie outside the area of common support. For hypotheses 1A, 2A, and 3A on the insurgency onset I used all the countryyears in the dataset. For hypotheses 1B, 2B, and 3B I included only insurgency countryyears. I use MatchIt software to conduct the matching (Ho et al. 2007a, Ho et al. 2007b).

Once the units are matched I check the balance between the treatment and control group to see whether the distance between them is minimized (examples of balance statistics are in the online appendix).

The balance statistics show that a perfect balance was not achieved, but the two groups are much closer to each other after matching than before. I therefore include the confounding variables in the post-estimation regression to reduce the role of the functional form and to produce more reliable causal inferences, as recommended by Ho et al (2007a, p. 201). 
References

Achen, Christopher and Duncan Snidal. 1989. Rational Deterrence Theory and Comparative Case Studies. World Politics 41(2):143-169.

Arreguin-Toft, Ivan. 2005. How the Weak Win Wars. Cambridge, MA: Cambridge University Press.

Barro, Robert J. 1999. Determinants of Democracy. Journal of Political Economy 107(S6):158-183.

Beck, Nathaniel, Katz, Jonathan N., and Richard Tucker. 1998). Taking Time Seriously in Binary Time-Series Cross-Section Analysis. American Journal of Political Science 42(4):1260-1288.

Bennett, D. Scott, and Allan Stam. 1996. The Duration of Interstate Wars, 18161985. American Political Science Review 90:239-257.

Berman, Eli, Jacob N. Shapira, and Joseph H. Felter. 2009. Can Hearts and Minds Be Bought? The Economics of Counterinsurgency in Iraq. NBER Working Paper No. 14606.

Bueno de Mesquita, Bruce, James D. Morrow, Randolph M. Siverson, and Alastair Smith. 2003. The Logic of Political Survival. Cambridge, MA: The MIT Press.

Bueno de Mesquita, Bruce, James D. Morrow, Randolph M. Siverson, and Alastair Smith. 2004. Testing Novel Implications from the Selectorate Theory of War. World Politics 56(3):363-388. 
Bueno de Mesquita, Bruce and Alastair Smith. 2009. A Political Economy of Aid. International Organization 63(2):309-340.

Caverley, Jonathan. 2009. Why Democracies Will Continue to Fight Small Wars Poorly:

Evidence from United States Involvement in the Vietnam War. International Security 34(3):119-157.

Cheibub, Jose Antonio, Jennifer Gandhi, and James Raymond Vreeland. 2009.

Democracy and Dictatorship Revisited Codebook, v.1. Can be downloaded from https://netfiles.uiuc.edu/cheibub/www/DD\_page.html.

Collier, Paul and Anke Hoeffler. 1998. On Economic Causes of Civil War. Oxford Economic Papers 50(4):563-573.

Elbadawi, Ibrahim and Nicholas Sambanis. 2002. How Much War Will We See?

Explaining the Prevalence of Civil War. Journal of Conflict Resolution 46(3):307-334.

Engelhardt, Michael. 1992. Democracies, Dictatorships, and Counterinsurgency: Does Regime Type Really Matter? Conflict Quarterly 12:52-63.

Europa World Plus. Accessed through the NYU library. http://www.europaworld.com/pub/about.

Fearon, James. 2002. Selection Effects and Deterrence. International Interactions 28(1):5-29.

Fearon, James, D., and David D. Laitin. 2003. Ethnicity, Insurgency, and Civil War. American Political Science Review 97(1):75-90. 
Fearon, James, D. and David D. Laitin. 2009. Sons of the Soil, Migrants, and Civil War. World Development, forthcoming.

Feaver, Peter and Christopher Gelpi. 2004. Choosing Your Battles: American CivilMilitary Relations and the Use of Force. Princeton, NJ: Princeton University Press.

Galula, David. 1964. Counterinsurgency Warfare: Theory and Practice. New York, NY: Praeger.

Gartner, Scot Sigmund and Randolph M. Siverson. 1996. War Expansion and War Outcome. Journal of Conflict Resolution 40(1):4-15.

Gilligan, Michael, J., and Ernest J. Sergenti. 2008. Do UN Interventions Cause Peace? Using Matching to Improve Causal Inference. Quarterly Journal of Political Science 3(2):89-122.

Gleditsch, Kristian Skrede. 2002. All International Politics Is Local: The Diffusion of Conflict, Integration, and Democratization. Ann Arbor, MI: University of Michigan Press.

Gleditsch, Kristian Skrede and Andrea Ruggeri. 2010. Political Opportunity Structures, Democracy, and Civil War. Journal of Peace Research 47(3):299-310.

Gleditsch, Nils Petter; Peter Wallensteen, Mikael Eriksson, Margareta Sollenberg, and Håvard Strand. 2002. Armed Conflict 1946-2001: A New Dataset. Journal of Peace Research 39(5): 615-637. Version 4-2009 of the dataset.

Gurr, Ted. 1970. Why Men Rebel. Princeton, NJ: Princeton University Press. 
Hegre, Håvard, Tanja Ellingsen, Scott Gates, and Nils Petter Gleditsch. 2001. Toward a Democratic Civil Peace? Democracy, Political Change, and Civil Wars, 1816-1992. American Political Science Review 95(1):33-48.

Hicken, Allen, Shanker Satyanath, and Ernest Sergenti. 2005. Political Institutions and Economic Performance: The Effects of Accountability and Obstacles to Policy Change. American Journal of Political Science 49(4):897-907.

Ho, Daniel, Kosuke Imai, Gary King, and Elizabeth Stuart. 2007a. Matching as Nonparametric Preprocessing for Reducing Model Dependence in Parametric Causal Inference. Political Analysis 15:199-236.

Ho, Daniel, Kosuke Imai, Gary King, and Elizabeth Stuart, 2007b. Matchit: Nonparametric Preprocessing for Parametric Causal Inference. Journal of Statistical Software, copy at http://gking.harvard.edu/matchit/.

Hoffmann, Stanley, Samuel P. Huntington, Ernest R. May, Richard N. Neustadt and Thomas C. Schelling. 1981. Vietnam Reappraised. International Security 6(1):3-26. Honaker, James, Gary King, and Matthew Blackwell. 2010. AMELIA II: A Program for Missing Data. Version 1.2-16.

Imai, Kosuke, Gary King and Olivia Lau. 2006. Zelig: Everyone's Statistical Software. http://GKing.Harvard.Edu/zelig.

Iyengar, Radha and Jonathan Monten. 2008. Is There an "Emboldenment" Effect? Evidence from the Insurgency in Iraq. NBER Working Paper No. 13839. 
Jensen, Nathan and Leonard Wantchekon. 2004. Resource Wealth and Political Regimes in Africa. Comparative Political Studies 37(7):816-841.

Kalyvas, Stathis. 2006. The Logic of Violence in Civil War. New York, NY: Cambridge University Press.

Karol, David and Edward Miguel. 2007. The Electoral Cost of War: Iraq Casualties and the 2004 U.S. Presidential Election. Journal of Politics 69(3): 633-648.

Keefer, Philip. 2007. Insurgency and Credible Commitment in Autocracies and Democracies. World Bank - Development Research Group (DECRG).

King, Gary and Langche Zeng. 2006. The Dangers of Extreme Counterfactuals. Political Analysis 14(2):131-159.

Krepinevich, Andrew, F. 1988. The Army and Vietnam. Baltimore, MD: The Johns Hopkins University Press.

Lacina, Bethany. 2006. Explaining the Severity of Civil Wars. Journal of Conflict Resolution 50(2):276-289.

Leitis, Nathan and Charles Wolf, Jr. 1970. Rebellion and Authority: An Analytic Essay on Insurgent Conflicts. A Report Prepared for the Advanced Research Projects Agency. R-462-APRA. Rand Corporation. http://www.rand.org/pubs/reports/2006/R0462.pdf.

Li, Quan. 2005. Does Democracy Promote or Reduce Transnational Terrorist Incidents? Journal of Conflict Resolution 49(2):278-297. 
Lyall, Jason and Isaiah Wilson III. 2009. Rage Against the Machines: Explaining Outcomes in Counterinsurgency Wars. International Organization 63(1):67-106

Lyall, Jason. 2010. Do Democracies Make Inferior Counterinsurgents? Reassessing Democracy's Impact on War Duration and Outcomes. International Organization 64(1): $167-92$.

Mack, Andrew. 1975a. Why Big Nations Lose Small Wars: The Politics of Asymmetric Conflict. World Politics 27(2):175-200.

Mach, Andrew. 1975b. Counterinsurgency in the Third World: Theory and Practice. British Journal of International Studies 1:226-253.

Marshall, Monty G. and Keith Jaggers. 2009. Polity IV Project: Political Regime Characteristics and Transitions, 1800-2007. Version p4v2007. College Park, MD: Center for International Development and Conflict Management, University of Maryland.

Merom, Gil. 2003. How Democracies Lose Small Wars: State, Society, and the Failures of France in Algeria, Israel in Lebanon, and the United States in Vietnam. Cambridge, MA: Cambridge University Press.

Miguel, Edward, Shanker Satyanath, and Ernest Sergenti. 2004. Economic Shocks and Civil Conflict: An Instrumental Variable Approach. Journal of Political Economy 112(4):725-753.

Montalvo, Jose, G., and Marta Reynal-Querol, forthcoming. Ethnic Polarization and the Duration of Civil Wars. Forthcoming in Economics of Governance. 
Morgan, T. Clifton and Sally Howard Campbell. 1991. Domestic Structure, Decisional Constraints, and War. So Why Kant Democracies Fight? Journal of Conflict Resolution 35 (2): 187-211.

Morgan, Stephen, L. and Christopher Winship. 2007. Counterfactuals and Causal inference. Methods and Principles for Social Research. NY: Cambridge University Press.

Morrow, James. 2007. When Do States Follow the Laws of War. American Political Science Review 101:3:559-572.

Record, Jeffrey. 2007. Beating Goliath: Why Insurgencies Win. Washington, D.C.: Potomac Books.

Reiter, Dan, and Allan C. Stam III. 2002. Democracies at War. Princeton, NJ: Princeton University Press.

Reynal-Querol, Marta. 2002. Ethnicity, Political Systems, and Civil War. Journal of Conflict Resolution 46(1):29-54.

Ross, Michael. 2009. Oil and Democracy Revisited. Working Paper. University of California at Los Angeles.

Sambanis, Nicholas. 2001. Do Ethnic and Nonethnic Civil Wars Have the Same Causes? A Theoretical and Empirical Inquiry (part I). Journal of Conflict Resolution 45 (3): 25982.

Sarkees, Meredith Reid. 2000. The Correlates of War Data on War: An Update to 1997. Conflict Management and Peace Science 18(1):123-144. 
Smith, Alastair. 1995. Alliance Formation and War. International Studies Quarterlu 39:405-425.

Valentino, Benjamin, Paul Huth, and Gylan Balch-Lindsay. 2004. Draining the Sea: Mass Killing and Guerrilla Warfare. International Organization 58(1):375-407.

Vreeland, James. 2008. The Effect of Political Regime on Civil War: Unpacking Anocracy. Journal of Conflict Resolution 52(3):401-425.

Wantchekon, Leonard. 2004. The Paradox of "Warlord" Democracy: A Theoretical Investigation. American Political Science Review 98(1):17-33.

Wood, Elizabeth Jean. 2000. Forging Democracy from Below: Insurgent Transitions in South Africa and El Salvador. Cambridge, MA: Cambridge University Press.

World Bank. 2007. World Development Indicators (WDI).

Zhukov, Yuri. 2007. Examining the Authoritarian Model of Counterinsurgency: The Soviet Campaign against the Ukrainian Insurgent Army. Small Wars and Insurgencies $18(3): 439-466$. 
Table 1: Coding insurgency outcomes

\begin{tabular}{|c|l|c|}
\hline Category & Explanation & $\%$ of cases \\
\hline 4 & Government wins, insurgents cease ti exist & $40 \%$ \\
\hline 3 & $\begin{array}{l}\text { Government wins, but extends minor concessions to insurgents } \\
\text { (provision of public goods to the separatist area or jobs to } \\
\text { former insurgents, excluding autonomy or power sharing) }\end{array}$ & $19 \%$ \\
\hline 2 & $\begin{array}{l}\text { A draw with the government providing major concessions } \\
\text { (power-sharing in the government or a greater regional } \\
\text { autonomy) }\end{array}$ & $16 \%$ \\
\hline 1 & $\begin{array}{l}\text { Violence ends temporary (less than 25 casualties per year), but } \\
\text { restarts again after less than 2 years }\end{array}$ & $7 \%$ \\
\hline 0 & $\begin{array}{l}\text { Insurgents win by overthrowing the incumbent or gaining } \\
\text { independence }\end{array}$ & $18 \%$ \\
\hline
\end{tabular}


Table 2: The effect of Polity $2 \geq 7$ on insurgency onsets and outcomes

\begin{tabular}{|c|c|c|c|c|}
\hline & \multicolumn{2}{|c|}{ Onsets (hypothesis 1A) } & \multicolumn{2}{|c|}{ Outcomes (hypothesis 1B) } \\
\hline & (1) & (2) & (3) & (4) \\
\hline & pre-matching & matched & pre-matching & matched \\
\hline & sample & sample & sample & sample \\
\hline & & treatment: & & treatment: \\
\hline & & Polity $2 \geq 7$ & & Polity $2 \geq 7$ \\
\hline Democracy & -0.006 & $-0.201 *$ & $-0.031 * * *$ & -0.411 \\
\hline \multirow[t]{2}{*}{ (Polity $2 \geq 7$ ) } & $(0.005)$ & $(0.119)$ & $(0.011)$ & $(0.256)$ \\
\hline & $-0.195 * *$ & $-0.310 * * *$ & $0.154 *$ & -0.033 \\
\hline \multicolumn{5}{|l|}{$\log$ GDP pc } \\
\hline & $(0.04)$ & $(0.062)$ & $(0.081)$ & $(0.124)$ \\
\hline & $0.108 * * *$ & $0.126 * * *$ & $0.132 * *$ & 0.157 \\
\hline \multicolumn{5}{|l|}{ log Population } \\
\hline & $(0.025)$ & $(0.042)$ & $(0.060)$ & $(0.102)$ \\
\hline Ethnic & $0.597 * * *$ & $0.514 *$ & -0.200 & $-0.742 *$ \\
\hline fractionalization & $(0.126)$ & $(0.226)$ & $(0.257)$ & $(0.445)$ \\
\hline Religious & -0.198 & -0.298 & $0.617 *$ & 0.189 \\
\hline fractionalization & $(0.158)$ & $(0.273)$ & $(0.348)$ & $(0.627)$ \\
\hline
\end{tabular}




\begin{tabular}{|c|c|c|c|c|}
\hline Non-continuous & 0.151 & $0.434 * *$ & $-0.374 * *$ & $-0.507 *$ \\
\hline \multirow[t]{2}{*}{ territory } & $(0.091)$ & $(0.135)$ & $(0.170)$ & $(0.300)$ \\
\hline & $0.054^{*}$ & 0.021 & 0.049 & -0.035 \\
\hline \multicolumn{5}{|l|}{ log Mountainous } \\
\hline & $(0.025)$ & $(0.047)$ & $(0.052)$ & $(0.096)$ \\
\hline & $0.251 * *$ & 0.108 & $0.303 *$ & 0.146 \\
\hline \multicolumn{5}{|l|}{ Oil } \\
\hline & $(0.092)$ & $(0.214)$ & $(0.165)$ & $(0.351)$ \\
\hline Foreign support & & & -0.058 & 0.178 \\
\hline for the government & & & $(0.112)$ & $(0.191)$ \\
\hline Foreign support & & & -0.046 & -0.265 \\
\hline \multirow[t]{2}{*}{ for the insurgents } & & & $(0.125)$ & $(0.233)$ \\
\hline & $-1.725 * * *$ & -0.723 & $-4.259 * * *$ & $-2.621 *$ \\
\hline \multicolumn{5}{|l|}{ Intercept } \\
\hline & $(0.407)$ & $(0.689)$ & (1.004) & $(1.458)$ \\
\hline $\mathrm{N}$ & 6794 & 3145 & 1151 & 403 \\
\hline
\end{tabular}


Table 3: the effect of $\mathrm{W} \geq 0.75$ on insurgency onsets (hypothesis $2 \mathrm{~A}$ )

\begin{tabular}{|c|c|c|c|c|c|c|}
\hline & (1) & (2) & (3) & (4) & (5) & (6) \\
\hline & $\begin{array}{c}\text { all } \\
\text { insurgencies }\end{array}$ & $\begin{array}{l}\text { all } \\
\text { insurgencies }\end{array}$ & separatist & separatist & $\begin{array}{l}\text { center- } \\
\text { oriented }\end{array}$ & $\begin{array}{l}\text { center- } \\
\text { oriented }\end{array}$ \\
\hline \multirow[t]{2}{*}{$\mathrm{W} \geq 0.75$} & $-0.297 * *$ & $-0.312 * *$ & $-0.261 *$ & $-0.324 *$ & $-0.323 * *$ & $-0.274 *$ \\
\hline & $(0.108)$ & (0.124) & $(0.146)$ & $(0.172)$ & $(0.135)$ & $(0.153)$ \\
\hline \multirow[t]{2}{*}{ XCONST } & & 0.009 & & 0.030 & & -0.022 \\
\hline & & $(0.027)$ & & (0.037) & & $(0.033)$ \\
\hline \multirow[t]{2}{*}{$\log$ GDP pc } & $-0.116 * *$ & $-0.122 * *$ & -0.070 & -0.080 & $-0.181 * *$ & $-0.172 * *$ \\
\hline & $(0.054)$ & $(0.055)$ & $(0.071)$ & $(0.072)$ & $(0.072)$ & $(0.073)$ \\
\hline \multirow[t]{2}{*}{$\log$ Pop } & $0.102 * * *$ & $0.094 * *$ & $0.177 * * *$ & $0.173 * * *$ & -0.035 & -0.032 \\
\hline & $(0.037)$ & $(0.037)$ & (0.048) & (0.049) & $(0.054)$ & $(0.054)$ \\
\hline Ethnic & $0.659 * * *$ & $0.656 * * *$ & $0.749 * * *$ & $0.749 * * *$ & $0.525^{*}$ & $0.524 *$ \\
\hline frac'n & $(0.208)$ & $(0.208)$ & $(0.273)$ & $(0.273)$ & $(0.280)$ & $(0.280)$ \\
\hline Religious & -0.051 & -0.068 & -0.318 & -0.323 & 0.281 & 0.286 \\
\hline frac'n & $(0.230)$ & $(0.231)$ & $(0.307)$ & (0.308) & $(0.313)$ & $(0.312)$ \\
\hline Non-cont. & 0.162 & 0.171 & $0.278^{*}$ & $0.275^{*}$ & -0.245 & -0.242 \\
\hline
\end{tabular}




\begin{tabular}{|c|c|c|c|c|c|c|}
\hline territory & $(0.276)$ & $(0.119)$ & $(0.155)$ & $(0.155)$ & $(0.192)$ & $(0.193)$ \\
\hline \multirow[t]{2}{*}{ New state } & 0.300 & 0.363 & 0.495 & 0.502 & 0.211 & 0.210 \\
\hline & $(0.276)$ & $(0.276)$ & $(0.310)$ & $(0.310)$ & $(0.504)$ & $(0.505)$ \\
\hline $\log$ & 0.032 & 0.028 & -0.027 & -0.025 & $0.113 * *$ & $0.110 * *$ \\
\hline Mountain. & $(0.036)$ & $(0.036)$ & $(0.049)$ & $(0.049)$ & (0.047) & $(0.047)$ \\
\hline \multirow[t]{2}{*}{ Oil } & -0.05 & 0.011 & -0.379 & -0.355 & $0.373 * *$ & $0.366^{*}$ \\
\hline & $(0.163)$ & $(0.163)$ & $(0.260)$ & $(0.259)$ & $(0.187)$ & $(0.187)$ \\
\hline \multirow[t]{2}{*}{ Intercept } & $-1.676^{* *}$ & $-1.367 * *$ & $-2.461 * * *$ & $-2.371 * * *$ & -1.505 & -1.598 \\
\hline & $(0.582)$ & $(0.612)$ & $(0.804)$ & $(0.809)$ & (1.035) & (1.050) \\
\hline $\mathrm{N}$ & 3687 & 3687 & 3687 & 3687 & 3687 & 3687 \\
\hline
\end{tabular}


Table 4: The effect of $\mathrm{W} \geq 0.75$ on government victory (hypothesis $2 \mathrm{~B}$ )

(1)

pre-matching sample
(2)

matched sample

\begin{tabular}{|c|c|c|}
\hline & -0.171 & -0.054 \\
\hline \multicolumn{3}{|l|}{$\mathrm{W} \geq 0.75$} \\
\hline & $(0.195)$ & $(0.282)$ \\
\hline & & -0.032 \\
\hline \multirow[t]{2}{*}{ XCONST } & & $(0.057)$ \\
\hline & $0.382 * * *$ & $0.390 * * *$ \\
\hline \multirow[t]{2}{*}{$\log$ GDP pc } & $(0.138)$ & $(0.141)$ \\
\hline & 0.129 & 0.146 \\
\hline \multicolumn{3}{|c|}{ log Population } \\
\hline & $(0.100)$ & $(0.106)$ \\
\hline & -0.162 & -1.198 \\
\hline \multicolumn{3}{|c|}{ Ethnic fractionalization } \\
\hline & $(0.452)$ & $(0.457)$ \\
\hline
\end{tabular}


Non-continuous territory

$\log$ Mountainous

$$
\text { (0.086) }
$$

$$
0.210
$$

Oil

$$
\text { (0.250) }
$$

Foreign support for the$$
0.001
$$

government

$$
(0.195)
$$

Foreign support for the

$-0.055$

$-0.057$

insurgents

$(0.201)$

Intercept

$-5.073 * * *$ $-5.343 * * *$ 
$(1.683)$

(1.794)

$\mathrm{N}$

516

516

Standard errors in parentheses

$*(\mathrm{p} \leq 0.1), * *(\mathrm{p} \leq 0.05), * * *(\mathrm{p} \leq 0.01)$ 
Table 5: the effect of XCONST $\geq 3$ on insurgency onsets (hypothesis $3 \mathrm{~A}$ )

\begin{tabular}{|c|c|c|c|c|c|c|}
\hline & (1) & (2) & (3) & (4) & (5) & (6) \\
\hline & $\begin{array}{c}\text { all } \\
\text { insurgencies }\end{array}$ & $\begin{array}{l}\text { all } \\
\text { insurgencies }\end{array}$ & separatist & separatist & $\begin{array}{l}\text { center- } \\
\text { oriented }\end{array}$ & $\begin{array}{l}\text { center- } \\
\text { oriented }\end{array}$ \\
\hline \multirow[t]{2}{*}{$\mathrm{XCONST} \geq 3$} & -0.152 & 0.024 & -0.156 & -0.161 & -0.15 & 0.259 \\
\hline & $(0.118)$ & $(0.154)$ & $(0.153)$ & $(0.192)$ & $(0.166)$ & $(0.231)$ \\
\hline \multirow[t]{2}{*}{$\mathrm{W}$} & & $-0.508 *$ & & -0.014 & & $-1.073 * * *$ \\
\hline & & $(0.273)$ & & $(0.371)$ & & $(0.386)$ \\
\hline \multirow[t]{2}{*}{$\log$ GDP pc } & $-0.142 * *$ & -0.107 & -0.116 & -0.117 & $-0.165^{*}$ & -0.103 \\
\hline & $(0.064)$ & $(0.066)$ & $(0.081)$ & $(0.086)$ & $(0.089)$ & $(0.092)$ \\
\hline \multirow[t]{2}{*}{$\log$ Pop } & $0.145 * * *$ & $0.143 * * *$ & $0.153 * * *$ & $0.153 * * *$ & 0.062 & 0.068 \\
\hline & $(0.043)$ & $(0.043)$ & $(0.053)$ & $(0.053)$ & $(0.066)$ & $(0.068)$ \\
\hline \multirow[t]{2}{*}{ Ethnic frac'n } & $0.600 * *$ & $0.574 * *$ & $0.533^{*}$ & $0.534^{*}$ & 0.483 & 0.456 \\
\hline & $(0.231)$ & $(0.233)$ & $(0.295)$ & $(0.297)$ & $(0.330)$ & $(0.340)$ \\
\hline Religious & -0.089 & -0.0277 & -0.370 & -0.372 & 0.453 & 0.625 \\
\hline frac'n & $(0.270)$ & $(0.274)$ & $(0.335)$ & $(0.338)$ & $(0.408)$ & $(0.421)$ \\
\hline Non-cont. & $0.268 * *$ & $0.314 * *$ & $0.434 * *$ & $0.432 * *$ & -0.405 & -0.338 \\
\hline
\end{tabular}




\begin{tabular}{|c|c|c|c|c|c|c|}
\hline territory & 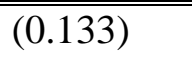 & $\overline{c(0.135)}$ & $(0.170)$ & $(0.172)$ & (0.249) & $\overline{c(0.258)}$ \\
\hline \multirow[t]{2}{*}{ New state } & 0.230 & 0.282 & 0.034 & 0.033 & $1.367 *$ & $1.536 * *$ \\
\hline & $(0.398)$ & (0.399) & $(0.505)$ & $(0.506)$ & $(0.740)$ & $(0.740)$ \\
\hline $\log$ & 0.031 & 0.027 & -0.015 & -0.015 & $0.135^{*}$ & $0.134 * *$ \\
\hline Mountain. & $(0.045)$ & $(0.046)$ & $(0.058)$ & $(0.058)$ & $(0.065)$ & $(0.067)$ \\
\hline \multirow[t]{2}{*}{ Oil } & 0.056 & 0.013 & -0.433 & -0.432 & $0.412^{*}$ & 0.326 \\
\hline & $(0.205)$ & $(0.208)$ & $(0.393)$ & (0.394) & $(0.238)$ & $(0.247)$ \\
\hline \multirow[t]{2}{*}{ Intercept } & $-2.033 * * *$ & $-2.070 * * *$ & $-1.808 *$ & $-1.808^{*}$ & $-5.870 * *$ & $-6.162 * * *$ \\
\hline & $(0.715)$ & $(0.718)$ & $(0.931)$ & $(0.931)$ & (2.305) & (2.332) \\
\hline $\mathrm{N}$ & 3420 & 3420 & 3420 & 3420 & 3420 & 3420 \\
\hline
\end{tabular}


Table 6: The effect of XCONST $\geq 3$ on government victory (hypothesis 3B)

(1)

pre-matching sample
(2)

matched sample

\begin{tabular}{|c|c|c|}
\hline & -0.142 & -0.213 \\
\hline \multicolumn{3}{|l|}{$\mathrm{XCONST} \geq 3$} \\
\hline & $(0.275)$ & $(0.306)$ \\
\hline & & 0.244 \\
\hline \multirow[t]{2}{*}{$\mathrm{W}$} & & $(0.470)$ \\
\hline & $0.326 * *$ & $0.304 *$ \\
\hline \multirow[t]{2}{*}{$\log$ GDP pc } & $(0.154)$ & $(0.160)$ \\
\hline & -0.042 & -0.045 \\
\hline \multicolumn{3}{|c|}{ log Population } \\
\hline & $(0.123)$ & $(0.124)$ \\
\hline & -0.041 & -0.083 \\
\hline \multicolumn{3}{|c|}{ Ethnic fractionalization } \\
\hline & $(0.524)$ & $(0.530)$ \\
\hline
\end{tabular}


Religious fractionalization $\quad(0.622)$

$(0.623)$

$-0.843 * *$

$-0.859 * *$

Non-continuous territory

(0.384)

$(0.384)$

New state

NA

NA

$-0.003$

0.001

$\log$ Mountainous

(0.099)

$(0.099)$

0.381

0.443

Oil

$(0.328)$

$(0.347)$

Foreign support for the

0.078

0.084

government

(0.211)

(0.212)

Foreign support for the

0.159

0.178

insurgents

(0.246)

(0.249)

Intercept

$-3.560 *$

$-3.469 *$ 
Notes

${ }^{1}$ For the purpose of this paper, insurgencies refer to armed rebellions of non-state groups against governments for the purpose of gaining control over the central government or achieving a greater regional autonomy or independence. Insurgencies, in this context, are not limited to a particular military strategy employed by the rebels. Empirically, I rely on the Armed Conflicts Dataset (Gleditsch 2002, version 4, 2009) that identifies various types of conflicts, such as coups, guerrilla warfare, urban insurgencies, civil wars, and conflicts of lower intensity. Details on the coding of variables are in Appendix A. Throughout the paper I use the terms insurgency and counterinsurgency interchangeably, with the former describing such conflicts from the insurgents' point of view and the latter from the government's.

${ }^{2}$ For classical works that recommend a "population-centered" approach to counterinsurgency see Galula (1964) and Krepinevich (1988).

${ }^{3}$ The dataset and the replication files will be posted on the author's webpage.

${ }^{4}$ Version 4 of the Armed Conflicts Dataset 2009.

${ }^{5}$ Similar definitions see in Fearon and Laitin 2003 and 2009 and Lyall 2010.

${ }^{6}$ Polity 2 ranges from a -10 (the most autocratic) to a 10 (the most democratic). For full explanation see Marshall and Jaggers (2009). 
${ }^{7}$ The measure of $\mathrm{W}$ is based on 4 components: REGTYPE, which is an indicator of regime type from Arthur Banks 1996, XRCOMP, XROPEN, and PARCOMP from Polity IV. One point is awarded to $\mathrm{W}$ if REGTYPE $\neq 2,3$, or it is not a missing value; Another point is awarded if $\mathrm{XRCOMP} \geq 2$; A third point is awarded if $\mathrm{XROPEN}>2$; A forth point is awarded if PARCOMP=5. Then the sum is divided by 4 (Bueno de Mesquita et al. 2003, 134-135).

${ }^{8}$ Hicken, Satyanath, and Sergenti 2005 also use this variable in their analysis.

${ }^{9}$ Civil wars are usually defined as conflicts that cross the 1000 casualties' threshold. ${ }^{10}$ Miguel, Satyanath, and Sergenti (2004) use the Armed Conflict Dataset (Gleditsch 2002) definition of conflict (above 25 annual deaths) and find that Polity score is not related to onsets of domestic conflicts. Gleditsch (2002) and Gleditsch and Ruggeri (2010) that also use the lower-threshold definition of conflicts, find evidence that democracy is related to a lower risk of conflict onset.

${ }^{11}$ For example, countries with higher income tend to be more democratic (Barro 1999), and they also have more mechanized armies (Caverley 2009). Mechanization is negatively associated with counterinsurgency victory (Lyall and Wilson 2009; Caverley 2009; Lyall 2010). This might account for the correlation that some observe between democracy and losses (Mack 1975a; Merom 2001), but it also shows that such correlation might be spurious. 
${ }^{12}$ See Gilligan and Sergenti 2008 for an application of matching to estimate the causal effect of UN interventions on civil wars. Lyall 2010 also uses matching to estimate the effect of regime type on counterinsurgency outcomes.

${ }^{13}$ I do not include anocracy and instability as independent variables because they are affected by insurgencies, as shown in Vreeland 2008.

${ }^{14}$ The reason for this exclusion is that if public goods are the key to a successful counterinsurgency, then this argument might not apply to cases in which the insurgents are not part of the democratic political system, and thus do not enjoy the public goods provided by democratic leaders to their constituencies.

${ }^{15}$ The reason for this exclusion is that if public goods are the key to a successful counterinsurgency, then this argument might not apply to cases in which the insurgents are not part of the democratic political system, and thus do not enjoy the public goods provided by democratic leaders to their constituencies.

${ }^{16}$ The dataset and the replication files will be posted on the author's webpage.

${ }^{17}$ Version 4 of the Armed Conflicts Dataset 2009.

${ }^{18}$ Similar definitions see in Fearon and Laitin 2003 and 2009 and Lyall 2010.

${ }^{19}$ For some countries the data were not available from this version, and for them I used LEVEL56 and LEVEL61 variables from Cheibub, Ghandi, and Vreeland 2009. 